\section{OBJECTIONS CONSIDERED.}

'To my esteemed friend Dr. Trudeau's objection to cremation on religious and ethical grounds I make no reply, except to honor him for his high sentiments. To Judge Ommen I feel particularly grateful for his elaborate reply. Concerning his legal objection I refer him to Dr. Janeway's letter, and what I said above about postmortcm examination of the body as a whole and the chemical analysis of stomach and intestines of all bodies before cremation. In reply to the pessimistic sentiments expressed-for example, that this world is growing colder and colder-I must take issue with my good friend.

Those of us who are interested in practical philanthropy will bear out my statement when I say that, on the contrary, there never has been so much practical good done to our less fortunate fellow men as in our time. More noble men and women devote their lives to the amelioration of suffering now than at any other time in the history of mankind. When the Hon. Alfred E. Ommen enters on ethical aspects and speaks of sentiment and affection I feel that my own power of expression will not be sufficient to convince him. I simply wonder what he means when he speaks of cremation as something unnatural, and why he considers it an entire obliteration.

How can a sentiment which is purely imaginary be of real benefit to mankind? The only uplifting influence that could come from a grave would be from the thought that there was something left there to be loved. One look at the real contents of a grave would remove this sentiment forever. It is the memory of the loved one, the influence of his noble actions, the results of his goodness that remain to guide, help and uplift. us. The grave merely symbolizes this through our early associations and religious training. Could not ashes and an urn symbolize this as well as decay and corruption and a mound of earth? Has not our immortal Longfellow, poet and seer, told us:

"Dust thou art, to dust returnest, was not spoken of the soul."

The following beautiful words from the Rev. Thomas R. Slicer on the subject will, I know, answer Judge Ommen's objections to cremation on ethical and sentimental grounds much better than I, with only a medical training, could possibly do:

$I$ approve of cremation as a means of returning by the quickest possible process the chemical constituents of the body to the earth, to which that body is nearly related. The decay of the grave is combustion. It seems rational to accomplish in three hours what is badly done by the slower processes in thirty years. Nothing seems to me a more direct affront to Nature than hermetically to seal up a human body and then place it in the ground, as though one defied Nature to have access to that which belongs to it. I think no one can witness the incineration of a human body without feeling that a clean flame has sincerely and quickly disposed of the only part of the body which can be consumed, leaving the remainder to be returned to the earth as it was. I do not see how there can be any religious objection to cremation, except from the standpoint of those who believe in the resurrection of the physical body; but as all intelligent students now who believe in immortality rather believe that you can not bury a man and that eternal life is a condition and not a place, this objection from the religious standpoint must soon disappear. Feeling, as I do, that all the real relations are spiritual, and that everything else is incidental to the communion of one human soul with another, I shall be glad to see the time when society shall more generally approve of disposing of the house of life by means which shall remove its decaying structure quickly and with the least danger to the survivors. The fundamental proposition in my thinking is that man has a body, but man is a spirit. I have always felt that the seabird that flew back and forth over the flame in which Shelley's body was consumed on the shores of the Mediterranean might very well typify a liberated soul which stayed its flight awhile to watch its cage consume. 16 West Ninety-fifth street.

[For tile Discussion on the Papers of Drs. Holden, Haynes and Wheaton (Published January 19) and Beggs ANd KNOPf, SEE PAge 360.]

\section{THE OPSONIC CONTENT OF THE BLOOD OF INFANTS.* \\ SAMUEL AMBERG, M.D. \\ Associate in Pediatrics, Johns Hopkins University. BALTIMORE.}

In $1901 \mathrm{Moro}^{1}$ pointed out that the bactericidal power of the blood serum of breast-fed infants markedly exceeds that of artificially fed ones. It was thought of interest to determine the opsonic content of the blood of infants raised under different conditions; particularly as the recent researches of Wright, his pupils and other investigators here and abroad seem to show that these substances which prepare the bacteria for phagocytosis play an important rôle in the defense of the organism against certain forms of bacterial invasion. The method employed to determine the opsonic content of the blood was that described by Simon and Lamar, ${ }^{2}$ and I adhered the more closely to this method, as I intended to compare my results with those obtained by Simon in adults. Furthermore, the method of Simon recommended itself for another reason. The work can be carried out without assistance and without continued comparison with normal individuals.

\section{PROCEDURE.}

Briefly, the procedure is as follows:

The serum is diluted with a 1 per cent. saline solution in a proportion of 1 to 20 by means of a pipette used in the counting of white corpuscles. Then twice nine divisions of the pipettee are put in a small glass tube. In preparing a dilution of $]$ to 40 nine divisions of the dilution 1 to 20 are mixed with nine divisions of the saline solution. The tubes are then charged with bacteria directly from an agar tube. Lastly, the equivalent of 6 divisions of an emulsion of blood corpuscles containing the leucocytes is added from a specially calibrated pipette. In this manner the total amount of fluid contained in each tube corresponds to 24 divisions of the pipette. The blood corpuscle emulsion is obtained in the usual way. The blood is taken up in a 0.1 per cent. solution of ammonium oxalate in 1 per cent. solution to prevent coagulation. The blood corpuscles are sedimented and washed three times with 1 per cent. saline solution with the help of the centrifuge. Finally, the supernatant fluid is pipetted off as completely as possible and the sediment is stirred up. The charged tubes are kept in the incubator for one-half hour. Smears are made and stained with alkaline aqueous methylene blue, so that the red blood corpuscles remain unstained. Then the percentage of leucocytes which have taken up bacteria is determined.

In most cases 50 cells were counted and this proved sufficient, since the counts of the first 25 cells agreed

\footnotetext{
- From the chlldren's department of the Johns Ilopkins Unl versity.

* Read in the Section on Diseases of Children of the Am rrican Medical Asiocintion at the Fifty-seventh Annual Session. June, 1906. 1. "Biologische Bezlchhungen zwischen Milch und Serum," Wien. klin. Wochschr.. 1901, p. 1073. The objectlons of Schutz (Jahrb. f. Kindhlk., 1905, |xi, p. 122) do not seem to be valid, since his method of experimentation does not seem to permit of a comparion with the work of Moro.

2. Johns Honkins Hosp. Bull., January, 1906, xvil.
} 
very well in the great majority of cases with those of the second 25. In some instances, particularly when this agreement was not good, as many as 200 cells were counted. In a number of cases not only the percentage of phagocyting leucocytes was determined, but at the same time the number of bacteria taken up by the single leucocytes were counted. The average number of bacteria taken up by a leucocyte designates the phagocytic power (Wright). Thus it was found that in cases in which, in a dilution of 1 to 20,100 per cent. of the leucocytes had taken up bacteria the values for the phagocytic power showed a great difference from those obtained when the serum was employed in greater concentrations. For instance:

\begin{tabular}{|c|c|c|}
\hline $\begin{array}{l}\text { Semm, } \\
\text { I. Concentrated } \\
1 \text { to } 20 \ldots \ldots \ldots \\
\text { 1I. Concentrated } \\
1 \text { to } 20 \ldots \ldots \ldots\end{array}$ & $\begin{array}{l}\ldots \ldots \\
\ldots \ldots \ldots \\
\cdots \ldots \\
\cdots \ldots\end{array}$ & $\begin{array}{c}\text { Percentage of } \\
\text { phagocy tosis. } \\
100 \\
100 \\
100 \\
100\end{array}$ \\
\hline
\end{tabular}

In cases in which the percentage of phagocytosis in a given dilution is very high, it may become necessary either to determine the phagocytic power or to employ higher dilutions in order to establish striking differences between the sera to be examined.

In 31 instances the phagocytic power was determined at the same time with the percentage of phagocytosis and the average phagocytic power was calculated which corresponded to the percentage of phagocytosis in the following manner:

\begin{tabular}{|c|c|c|}
\hline \\
\hline 90 & to & 100 \\
\hline 80 & to & 90 \\
\hline 70 & to & 80 \\
\hline 60 & to & 70 \\
\hline 50 & to & 60 \\
\hline 40 & to & 50 \\
\hline 30 & to & 40 \\
\hline 20 & to & 30 \\
\hline 10 & to & 20 \\
\hline
\end{tabular}

Phagocytic power.
9.7
$\mathbf{5 . 6}$
4.3
3.8
2.6
2.2
1.4
1.0
0.5

This table seems to indicate that, as a whole, a correspondence exists between the percentage of phagocytosis and the phagocytic power. It must be mentioned, however, that the individual values for the phagocytic power in the different groups showed rather considerable variations. This is probably due to the fact that the method employed does not permit an exact comparable determination of the phagocytic power. Thanks to the kindness of Dr. Potter, I was able to convince myself that the time which the serum is permitted to act on the mixture of bacteria and corpuscles, as well as the number of bacteria added, play an important rôle in regard to the number of bacteria taken up by the leucocytes. In the method I employed, the time consumed in the preparation of the single tubes was not the same for all the tubes, and the number of bacteria added in our experiments is necessarily subject to more or less wide variations. Whether these factors operate to the same extent in the dilutions employed is questionable. ${ }^{3}$ Nevertheless, it is very probable that, as a rule, a correspondence exists between the percentage of phagocytosis and the phagocytic power, particularly in the class of cases which I observed. In spite of the inherent crudeness of the method, the table may be taken as an expression of this relation without paying attention to the exactness of the figures.

In all my experiments the tubes were kept in the thermostat, for one-half hour, but from the following experiments it does not seem to make a material difference in regard to the percentage of phagocytosis whether the time of incubation is one-quarter or one-half hour.

3. These factors do not seem to play an equally important rôle in regard to the percentage of phagocytosis, at least not within limits easily to be controlled.
One-half hour.

Serum I. 1 to 20,88 per cent.

Serum I. 1 to 40,50 per cent.

Serum II. 1 to 40,4 per cent.

One-fourth hour.

92 per cent.

50 per cent.

6 per cent.

Hesting the serum to $59 \mathrm{C}$. for ten minutes prevented the phagocytosis completely. For instance, a serum onehalf diluted gave a phagocytosis of 100 per cent., while after heating no phagocytosis occurred.

A large number of control experiments were conducted, using saline solution in place of serum. Frequently these controls were entirely negative, but in a number of instances one or two cells were counted as positive. These cells contained one or two cocci, rarely as many as four. It was not always certain whether these cocci were actually in the cells, but these cells would in all probability have been counted as positive in the regular counts. In the figures given in my tables it was not deemed necessary to make any corrections, as this possible error seems to fall well within the errors of the method.

\section{ANALYSIS OF CASES.}

Although it is well known that different bacteria are not equally susceptible to phagocytosis I used only the Staphylococcus citreus. This seems to be permissible, since Simon ${ }^{4}$ has found that if the percentage of phagocytosis for a normal serum is high for one kind of bacterium it is correspondingly high for others, while the absolute values for the different organisms may vary considerably. It must be noted that we are not dealing here with immune opsonins and that cases of infection with Staphylococcus citreus are not very common so far as I am aware. The total number of cases examined was 45 . In only a few instances could the examinations be repeated, on account of the strong objections of the mothers.

The average percentage of phagocytosis in 20 normal adults was determined by Dr. Simon with the Staphylococcus citreus. He found for the dilution of 1 to $20,3 \%$ per cent.; for 1 to 40,9 per cent. The highest values for 1 to 20 were 72 per cent. ; for 1 to 40,42 per cent. The lowest for 1 to 20 was 12 per cent.; for 1 to 40 , 0 per cent. But there are individuals who present rather constantly higher values. Thus my own serum gave repeatedly for 1 to 2088 per cent.; for 1 to 40 , 50 per cent. In a few other individuals still higher values were obtained.

GROUP 1.

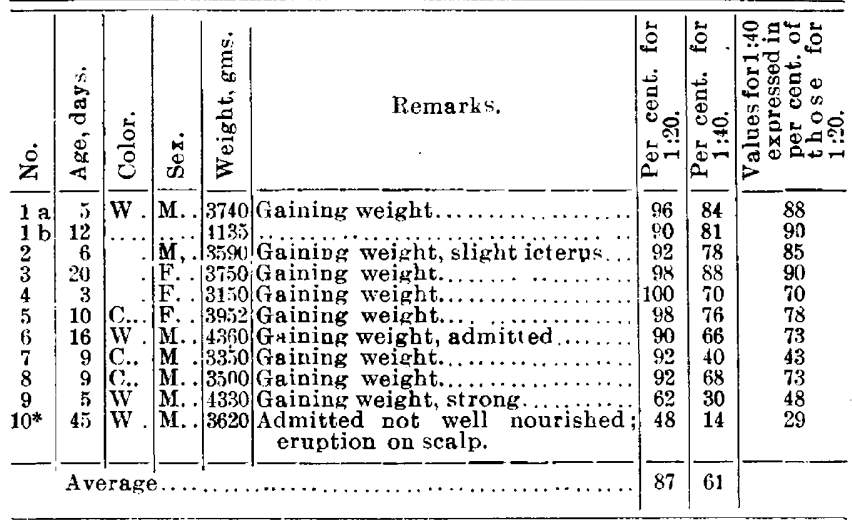

* About one and one-half months

My own cases may be divided into several groups. The first group is composed of 10 breast-fed infants varying in age from 3 days to about 11/2 months. These babies were inmates of the maternity ward of the Johns Hop-

4. Tour of Exp.-Med., viii, 1006, 6; also Am. Jour. Med. Sci., 1907 (about to appear). 
kins Hospital, and I express my indebtedness to Dr. Williams and to his staff for the courtesy with which they placed the material and their laboratory at my disposal.

Some of the members of this group had received occasionally some additional feeding besides the breast. But the breast fteding always greatly preponderated. Case 10 showed the lowest values. This infant was admitted to the hospital 3 or 4 weeks after birth with a weight of $3,500 \mathrm{gm}$. The state of nutrition was rather poor, but no special lesions could be made out. The other babies were all doing well. The average values of these cases are higher than those for normal adults. Wright ${ }^{5}$ states that the phagocytic power of the newborn infant equals about that of the mother. If we should be permitted to assume that the percentage of phagocytosis of the

GROUP 2.

\begin{tabular}{|c|c|c|c|c|c|c|c|c|}
\hline$\dot{\vec{z}}$ & & 苟 & $\begin{array}{c}\dot{A} \\
\dot{0} \\
\ddot{\infty}\end{array}$ & 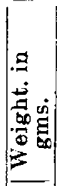 & Remarks. & 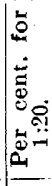 & 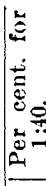 & 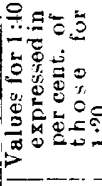 \\
\hline 1 & & w & F... & $\ldots$ & Mild pertussis; overfeeding; good & 90 & io & 56 \\
\hline 2 & $3 / 4$ & $\mathrm{w}$ & M. . & 3175 & $\begin{array}{l}\text { Vomiting; squamous eczema; two } \\
\text { days no food. }\end{array}$ & 94 & 66 & 70 \\
\hline & & w & M. & 6435 & $\begin{array}{l}\text { Irregular prolonged nursing: } \\
\text { strong; good nutrition. } \\
\text { Overfeeding; rachitis; exudative }\end{array}$ & 90 & 38 & 30 \\
\hline & & C... & & 2040 & $\begin{array}{l}\text { diathesis } \\
\text { Lues; rachitis; overfeeding....... } \\
\text { Lues. rachitis; slight overfeediug; }\end{array}$ & $\begin{array}{l}68 \\
32\end{array}$ & $\begin{array}{l}42 \\
16\end{array}$ & 50 \\
\hline \begin{tabular}{l|l}
7 & 9 \\
8 & 8 \\
8 & -1
\end{tabular} & & $\begin{array}{l}\mathrm{W} \\
\mathrm{W}\end{array}$ & M. . & $\left|\begin{array}{l}8420 \\
589 \bar{i}\end{array}\right|$ & $\begin{array}{l}\text { Mild bronchitis } \\
\text { Rachitis; bronchitis; irreg. feed } \\
\text { ing; alwass weak and cross; }\end{array}$ & $\begin{array}{l}82 \\
56\end{array}$ & $\begin{array}{l}48 \\
28\end{array}$ & 59 \\
\hline $9 \mid 3$ & & w & M. . & 5440 & $\begin{array}{l}\text { temp. 99.4. } \\
\text { Pertussis moderately severe; mild } \\
\text { bronchitis; overfeeding; temp. } \\
\text { 99.4. }\end{array}$ & 44 & 14 & \\
\hline 109 & & $\mathrm{w}$ & M. . & & $\begin{array}{l}\text { Right ear running; right cervical } \\
\text { glands enlarged; pale: mild } \\
\text { bronchitis; well nourished; } \\
\text { temp. 99. }\end{array}$ & 96 & 80 & 63 \\
\hline & & & & & & 70 & 42 & \\
\hline
\end{tabular}

mother's blood coincides with the values for normal adults, as determined by Simon, ${ }^{4}$ we would find an analogy for a discrepancy between the mother's and infant's blood in the results of Moro. ${ }^{1}$ He found that the bactericidal power of the serum of the newborn before feeding equals that of the placentar serum, while later on it increases markedly.

GROUP 3.

\begin{tabular}{|c|c|c|c|c|c|c|c|c|}
\hline 号 & 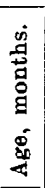 & 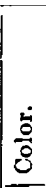 & 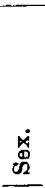 & 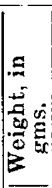 & Remarks. & 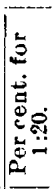 & 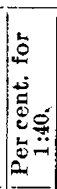 & 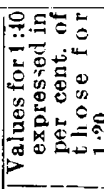 \\
\hline 1 & 11 & $\overline{\mathrm{C} ., .}$. & M. . & 6520 & Breast and oatmeal; rice., etc. & 74 & 48 & $6 i$ \\
\hline 2 & 2 & w. & & 5160 & $\begin{array}{l}\text { Rachitis; fairly well nourished } \\
\text { breast and cow's milk dilued; } \\
\text { constipated. }\end{array}$ & 64 & 6 & 9 \\
\hline 3 & $6 \frac{1}{2}$ & W.. & M.. & 6150 & $\begin{array}{l}\text { Breast. since two weeks, plus } \\
\text { diluted cow's milk, rachitis. }\end{array}$ & 100 & 64 & 64 \\
\hline 4 & 3 & C... & M. . & 3175 & $\begin{array}{l}\text { Breast and condensed milk; in } \\
\text { filtrated areas on head; wast- } \\
\text { ing since two weets. }\end{array}$ & 42 & 10 & 24 \\
\hline 5 & 3 & C... & M. . & & $\begin{array}{r}\text { Breast and cow's milk; cranio- } \\
\text { tabes; well nourished feeding } \\
\text { irreg.; vomiting; constipation. }\end{array}$ & 15 & 3 & \\
\hline 6 & 7 & C... & F. & 7340 & $\begin{array}{l}\text { Breast, since three months, plus } \\
\text { oatmeal bread, potatoes, etc. } \\
\text { slight rachitis; strong, weli } \\
\text { looking. }\end{array}$ & 53 & 10 & 65 \\
\hline & & & & & & 58 &. & \\
\hline
\end{tabular}

'The second group is composed of 10 breast-fed infants which were brought to the Johns Hoplins Hospital Chil-

5. Proc. Royal Soc., 1904, lxxiv, p. 147. dren Dispensary, ranging in age from 3 weeks to 9 months. These infants were suffering from different ailments, but their temperature did not exceed 99.4 .

In this group also additional feeding was given occasionally, but not regularly. The low values of Case 6 were obtained in a poorly nourished syphilitic baby 5 weeks of age. Here we have apparently to deal with a secondary malnutrition. Of interest is Case 4, with a phagocytosis of 46 per cent. and 14 per cent., respectively. Although the weight here does not indicate any disorder of the nutrition, nevertheless the anemia, an itching urticaria-like eruption of the skin, together with a scaly itching eruption and multiple areas of infiltration of the scalp with enlargement of the cervical glands and an erosion of the skin near the back of the head, mar. perhaps be taken as symptoms of the exudative diathesis of Czerny, ${ }^{6}$ in which a diminution of the normal immunity is supposed to exist.

The third group is composed of six cases, which received regularly, besides the breast, some other food. The age varies between 2 and 11 months.

The fourth group is composed of 13 artificially ferl babies, mostly fresh or condensed milk being used in these cases. The age varies between 10 weeks and 1; months.

GROUP 4

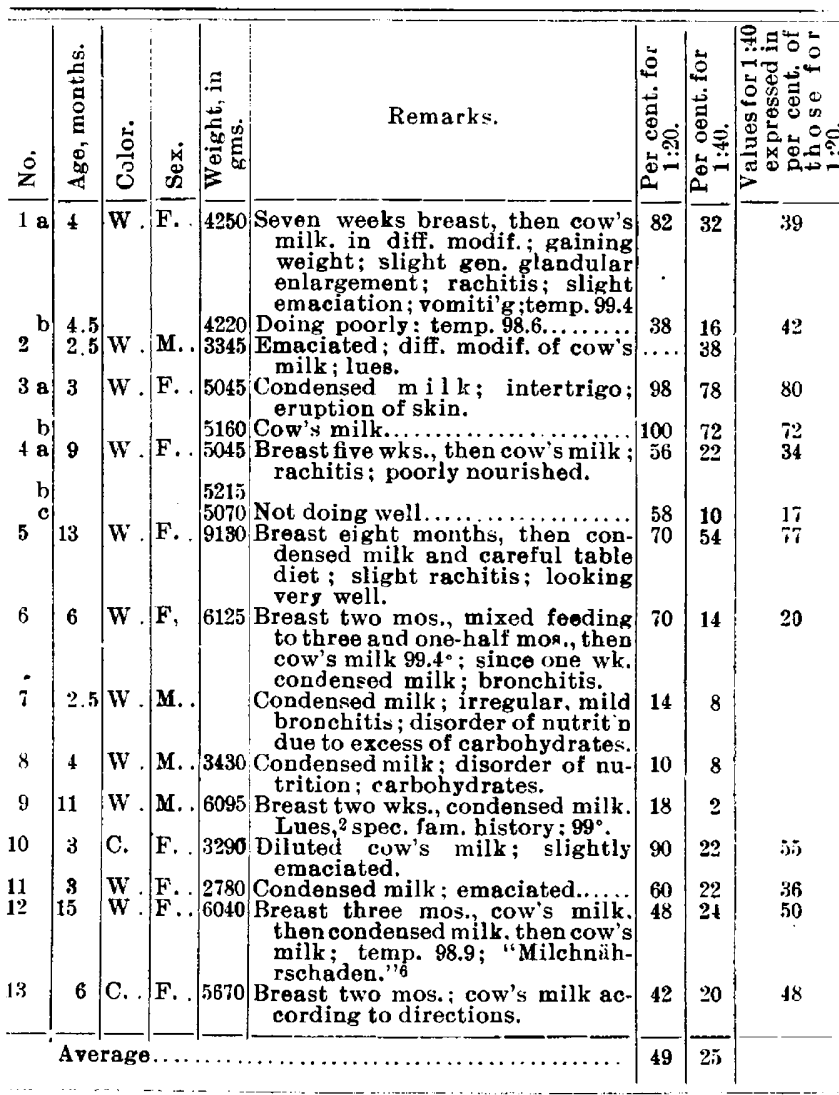

Cases 7 and 8 are of special interest. Both infants presented the clinical signs of a disorder of nutrition. e. g., alimentation, due to excess of carbohydrates, as described by Czerny and Keller. ${ }^{7}$ In both cases the percentage of phagocytosis is very low. This result would well support the clinical observation that the resistance of these infants toward infection is markedly dimin-

6. "Die Exudative Diathese," Jahrb. f. Kindhlk., 1005, lvi, p. 199 .

7. "Des kindes Ernährung, Ernährungsstörungen und Ernährungstherapie," ii. 
ished. Both were raised on condensed milk. But the infant in Case 3, which gave the highest values, was also raised on condensed milk, but in that case the symptoms attributable to a faulty diet were very mild. Therefore. there must be other factors besides the food which influence the opsonic content of an infant's blood.

The fifth group is made up of six cases, the age varying between 3 and 20 months. In four of these cases the temperature exceeded 100 , while the other two cases were too abnormal to be taken into consideration in the other groups.

GROUP 5.

\begin{tabular}{|c|c|c|c|c|c|c|c|c|}
\hline$\dot{0}$ & 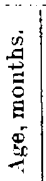 & : & $\stackrel{x}{\mathscr{D}}$ & 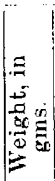 & Remarks, & 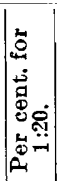 & 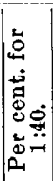 & 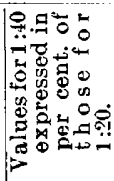 \\
\hline 1 & 20 & WV & $F$. & 7770 & $\begin{array}{l}\text { Rachitis; measles; ulcerative } \\
\text { stomatitis; bronchitis; temp. } \\
103.4^{\circ}\end{array}$ & 92 & 56 & E1 \\
\hline $2 \mathrm{a}$ & 4 & W & M. & 6350 & Art. fed; rachitis; bronchitis; & 51 & 26 & 46 \\
\hline $2 \mathrm{~b}$ & & & & 6125 & Temp. $101 . \ldots \ldots \ldots \ldots \ldots \ldots \ldots$ & 84 & 32 & 38 \\
\hline 3 & 3 & IV & $\mathrm{F}$. & & $\begin{array}{l}\text { Breast; intertrigo; papular ves- } \\
\text { icular eczema of limbs and } \\
\text { trunk; temp. 101.6. }\end{array}$ & 96 & 41 & $d$ \\
\hline 4 & 20 & W & $\mathrm{F}$. & 8364 & $\begin{array}{l}\text { Mixed feeding; indigestion; } \\
\text { temp. 101.4. }\end{array}$ & 92 & 64 & 70 \\
\hline $5 \mathrm{a}$ & 6 & c. & F. & & $\begin{array}{l}\text { Broast; accessory fingers on botb } \\
\text { hands; lues; hydrocephalus. }\end{array}$ & 86 & 22 & 20 \\
\hline $\begin{array}{l}5 \\
5 \\
6\end{array}$ & $i$ & Wi & $\mathbf{F}$ & $\begin{array}{l}4395 \\
3715\end{array}$ & $\begin{array}{l}\text { Losing weight } \\
\text { Breast: emaciated; anemic; } \\
\text { liverand spleen much enlarged; } \\
\text { leukopenia. }\end{array}$ & 66 & $\begin{array}{l}16 \\
14\end{array}$ & $\frac{22}{21}$ \\
\hline
\end{tabular}

The febrile cases were not classified in the other groups, since it is known that in acute diseases the phagocytic power may vary considerably, and Simon frequently found high values in such cases.

\section{RESULTS.}

Summing up the results obtained in our series of investigation, we have as arcrage values for the percentage of phagocytosis:

\begin{tabular}{|c|c|c|c|c|c|c|}
\hline & Avera & $\begin{array}{l}\text { fe per cent } \\
\text { for }\end{array}$ & 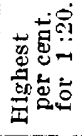 & 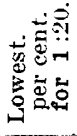 & 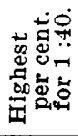 & 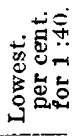 \\
\hline $\begin{array}{c}\text { Group } 1 . \\
\text { hospital } \\
\text { cases. } \ldots\end{array}$ & 87 & 61 & 100 & 48 & 88 & 14 \\
\hline Group 2. Breast-fed & & & & & & \\
\hline $\begin{array}{l}\text { dispensary cases. } \\
\text { Averaye for Groups }\end{array}$ & 70 & 42 & 96 & 32 & 80 & 14 \\
\hline 1 and 2 Mixed & 79 & 52 & $\ldots$ & . & $\cdots$ & . \\
\hline feeding $\ldots \ldots$ & 58 & 29 & 100 & 16 & 64 & 3 \\
\hline $\begin{array}{r}\text { Group } \\
\text { feeding } \\
\text { Artincial }\end{array}$ & 49 & 25 & 100 & 10 & 78 & 2 \\
\hline
\end{tabular}

A distinct advantage exists in favor of the breast-fed infants. But if we consider the individual values in the different groups and compare particularly the highest values of the different groups with each other, it is apparent that our results can not be brought in parallel with those of Moro." 'This author found that the serum of even very weak breast-fed infants exceeds in bactericidal power that of baloies artificially fed and doine well. Furthermore. when a breast-fed infant with a sertum of high bactericilal power had been fed on the bottle for two weeks the bactericidal power of its serum had decreased considerably. From his experiments the high alexin content of the broast-fed infant's blood seems to be directly a function of the breast milk, and he assumes the presence of alexogen substances in human milk. Some of the high values which are obtained in Group 4 do not permit us to bring the high opsonic content of the breast-fed infant's blood in direct relation to the liuman milk. While the kind of food may exercise a certain influence, other factors must enter into consideration. The state of nutrition seems to be one of these. Within certain limitations we may take the weight of an infant as an indication of the state of its nutrition. Since, with the exception of the first group, the birth weight could only be ascertained in a few cases, I will here only cite striking differences.

In Group 1 the lowest values were obtained in Case 10, which in relation to its age shows decidedly the lowest weight. In Group 2, Case 6 holds the same position as Case 10, Group 1, and here, too, the values were low. In Group 4 are 3 infants, each 3 months of age, and the ralues are: Case 3 , average weight, 5,$100 ; 1$ to 20,99 per cent.; 1 to 40,75 per cent. Case 10, weight, 3,290; 1 to 20,40 per cent.; 1 to 40,22 per cent. Case 11, weight, 2,$780 ; 1$ to 20,60 per cent.; 1 to 40,22 per cent. While in these cases the lowest weight does not coincide with the lowest values, nevertheless the greatest weight certainly is combined with the highest values.

But while we have cases indicating the state of nutrition as a factor in regard to the opsonic content of the blood of infants, there are other cases which do not show this influence very distinctly. Thus in Group 1 is Case 9 , a case in which the infant, according to its weight and its clinical aspect, was in a very good state of nutrition. Nevertheless the values obtained in this case were relatively low. In Group 2, Case 9 gave low values, in spite of the good weight. In Group 3, Case 5 gave the lowest values, although the baby seemed to be well nourished. In Group 4, Case 4 gave relatively high values, although the infant's weight was low for its age. Therefore, it is probable that still other factors enter into consideration besides the state of nutrition as expressed in the weight of the baby.

Case 4, Group 2, may be taken as one of exudative diathesis. This disorder is supposed to represent a congenital abnormality of the constitution. Although it is not permissible to draw any conclusion from a single observation in a single case, nevertheless this observation may indicate a factor which may govern the opsonic content of the blood, a faulty constitution. Only in a few cases a reliable family history could be obtained, so that no information can be obtained in regard to possible hereditary influences on the opsonic content of the infant's blood. It must be left to further investigations whether the so-called inherited predisposition of the offspring, for instance, of parents suffering with tuberculosis may find a manifestation in the opsonic content of the child's blood.

The average values obtained in my cases exceed somewhat those obtained by Simon ${ }^{4}$ in normal adults. Since Simon has shown that a longer period of abstinence from food tends to lower the opsonic content, a possibility exists that the more frequent feeding of infants may to some extent account for this observation. In Case 2, Group 2, the baby's weight was $3,135 \mathrm{gm}$., and the values recorded are for 1 to 20,94 per cent., and for 1 to 40,66 per cent. This baby had received the breast once within 48 hours, and that within the first 24 hours. It vomited promptly. The rest of the time it had been kept on water slightly sweetened with sugar. It was impossible to repeat the examination, so the possibility exists that the usual values may have been higher. Nevertheless it does not seem very probable that the influence of the fasting was a very marked one in this case. In Case 3, Group 1 , the values which represent an infant of about the same age but of a higher weight were for 1 to 20,98 per cent.. and for 1 to 40,84 per cent. 
In the last column of the tables the values obtained for the dilution of 1 to 40 are expressed in the percentage of those obtained for 1 to 20 . This calculation was omitted in cases in which the values for 1 to 20 were very low. In Group 1 this percentage was the lowest, where the absolute values were the lowest. In Group 2 the same holds good, with the exception of Case 6 . In Group 3, Case 2 gave a phagocytosis of 64 per cent. for 1 to 20 and of 6 per cent. for 1 to 40 . The value for 1 to 40 , expressed in the percentage of that for 1 to 20 , is 9 per cent., and this is the lowest value of this series. The difference is here very pronounced. In the other cases of this group the lowest value coincides with the lowest value for the phagocytosis. In Group 4, Case 1 is of interest. Here the absolute values differed markedly on two different examinations, while the percentage of the values for 1 to 40 in relation to those for 1 to 20 did not differ materially. Case 6 of this group corresponds to Case 2 of Group 3. The meaning of the values tabulated in the last column of the tables is not clear.

In summing up results, we must be careful in drawing conclusions from the data given. The dispensary material does not furnish an ideal material to reach final results, and the small number of cases in which the examinations could be repeated makes itself felt very disagreeably. Furthermore, it was impossible to obtain normal infants on which a series of observations covering a longer period of time could be taken, and such a series certainly is very desirable. Therefore, I offer these results only tentatively and more as a basis for further investigation.

Since the blood of normal individuals contains a certain amount of opsonins which are able to prepare a large number of different micro-organisms for phagocytosis, and since these opsonins seem of importance in the defense of the organism against various infections, it seems necessary to determine, if possible, the conditions which govern their amount in the blood of normal individuals. Keeping in mind the restriction mentioned above, the results may be summarized as follows:

1. The opsonic content of the infant's blood does not seen to follow the rules laid down by Moro ${ }^{1}$ for the bactericidal power of the blood.

2 . The average values for the opsonic content of the infant's blood exceed those laid down by Simon ${ }^{4}$ for normal adults.

3. A distinct advantage seems to exist in favor of the breast-fed infant. This advantage does not seem to be dependent as much on the breast feeding as such, but it seems to be dependent to some extent on the state of the nutrition of the infant and perhaps on the constitution. ${ }^{8}$

8. In the Herter lectures delivered in Baltimore in October. 1906, Wright cited the results obtained in the Great Ormond Stree rospital, London, England. Seventy-two infants were examined with regard to their opsonic index for streptococci in order to de termine the best time for the operation of cleft palate. It was found that the opsonic index was high (corresponding to that of the mother) during a certain time after birth; then a declded drop wother) during a certain time afer birth; then a declded drop was noted with an increase later on. If my results are calculated
with regard to the age solely the following results would be obtained: From birth to 1 month (10 observations). 1 to 20,91 per cent., and 1 to 40.67 per cent.; 1 month to 2 months (1 observation), 1 to 20,48 per cent., and 1 to 40.14 per cent.; 2 months to 3 months, 1 to 20,45 per cent. (4 observations), 1 to 40,22 per cent. (5 observations). 3 months to 4 months ( 6 observations), 1 to 20 , 50 per cent.. and 1 to 40,26 per cent., 4 months to 5 cent. ; 6 months to 7 months (3 observations), 1 to 20,71 per cent. and 1 to 40,33 per cent. These results seem to bear out the observations made in the Iondon Hospital. But with exception perhaps the first month the individual values of the different periods vary too much to permit the conclusion that the opsonic content is dependent on the age solely.

\section{SUPERSTITION IN TERATOLOGY.}

\author{
WITH SPECIAL REFERENCE TO THE THEORY OF \\ IMPRESSัTIONISM.* \\ EDWIN TAYLOR SHELLY, M.D. \\ ATCHISON, KaN.
}

Man has always and everywhere been the plaything of the supernatural, a helpless rodent under the cruel claws of the black cat of superstition. Now and then an individual has escaped from his tormentor, but for the vast hordes of humanity this has been impossible and continues so in varying degree in every inhabited portion of the globe to this day. To the whims and caprices of gods of its own making has mankind too easily been lead in the past to attribute every misfortune and every unusual natural phenomenon. No wonder, therefore, that the ancients often accounted in this way for the startling and sometimes hideous defects and deformities known to teratology.

\section{ANCIENT TERATOGENIC THEORIES.}

In the very earliest ages of the world it is probable that some of the terata were themselves deified, or were considered the progeny or at least the simulacra of the gods. Euhemerus was an ancient historian who accounted for the deities of Hellenic mythology by regarding "myths as traditional accounts of real incidents of human history." In this way euhemerism accounts for the teratologic appearance of many of the heathen gods and demi-gods, and we may, therefore, euhemerize Polyphemus into a cyclops fetus; the Centaur into a hydrocephalic calf; Atlas into a case of occipital encephalocele; Prometheus into a fetal exomphalos, etc.

Another theory held that monstrosities were created by the gods purely for their own amusement. This mudpie theory is supposed to survive in such terms as "freak of Nature" and "sport" in botany.

But this theory soon gave way to the monitory or minatory theory which kept a very firm hold on the minds of men for many ages. Monsters were a divine warning or threat and called for the propitiation of the offended diety, whether heathen or Christian, and the deformed infant soon came to be regarded as the proper sacrificial or propitiatory offering to the displeased celestial magnate. Even the mother at times met the same fate as her defective child.

Another theory regarded the appearance of a monster as an awe-inspiring manifestation of the glory and power of God.

Ever since earliest Christian history many persons have looked on the birth of a monster as a penalty for sins committed, a gruesome anthropomorphism still rampant among the ultra pious everywhere.

Associated with the belief in the teratogenic power of the Deity was the idea that evil spirits also possessed this power, and Ballantyne declares that the history of the effects of this notion is so "full of sad, revolting, repulsive and almost incredible incidents that no good purpose can be served by lingering over it, this darkest fancy of the dark ages."

Since the very carliest times the moon and the stars and their changing positions in the sky have been looked on as teratogenic causes. Those ancient experts in divination, the Chaldeans, felt so proficient in their art that they considered it an easy matter to tell not only what stellar combinations caused certain monstrosities, but

* Read in the Section on Diseases of Children of the American Ifedical Association at the Fifty-seventh Annual Session, June, 1906. 